\title{
Synthesis, Characterization and Biological Activity of Transition Metal Complexes of [1-(2-bromo, 5-methoxy benzylidene) hydrazine] Ligand
}

\author{
Nirmal Joshi ${ }^{1}$, Vishnu Gore, Sunil Tekale ${ }^{1}$, Dhanaji Rajani ${ }^{2}$, Saroj Bembalkar ${ }^{1, *}$, Rajendra Pawar 1,*(D) \\ 1 Department of Chemistry, Deogiri College, Aurangabad, Maharashtra, India \\ * Correspondence: s_bembalkar@yahoo.com (S.R.B.), rppawar@yahoo.com (R.P.P.); \\ Scopus Author ID 7003738785 (R.P.P.) \\ Scopus Author ID 36130867900 (S.R.B.) \\ Received: 18.09.2020; Revised: 14.10.2020; Accepted: 15.10.2020; Published: 17.10.2020
}

\begin{abstract}
A series of metal complexes was synthesized from the novel Schiff base [1-(2-bromo-5methoxybenzylidene)-hydrazine] ligand. The ligand and metal complexes were well characterized by spectroscopic methods. The ligand was found to be monodentate. Stoichiometry of the ligand to metal ions was confirmed to be 4:1. Furthermore, the synthesized metal complexes were screened for antimicrobial, antitubercular, and antimalarial activities, which revealed that $\mathrm{Cu}$ (II) and $\mathrm{Zn}$ (II) showed excellent antimicrobial activity, $\mathrm{Ni}$ (II) was active against M. Tuberculosis, and Cd (II) showed excellent antimalarial activity.
\end{abstract}

Keywords: antimicrobial; anti-tuberculosis; antimalarial; ligand and metal complexes.

(C) 2020 by the authors. This article is an open-access article distributed under the terms and conditions of the Creative Commons Attribution (CC BY) license (https://creativecommons.org/licenses/by/4.0/).

\section{Introduction}

Coordination chemistry is the study of co-ordinate bond between ligands and central metal atom. Schiff's bases are compounds having an imine $(\mathrm{C}=\mathrm{N})$ group [1]. Schiff's bases are formed by the condensation of an amine with a carbonyl group. Schiff's base ligands form coordination complexes with metal ions.

Imines constitute an important class of compounds for the synthesis of biologically active entities [2]. Schiff's bases possess remarkable properties due to chelating ability, stability, and antimicrobial activity [3]. They act as ligands for the synthesis of metal complexes. Complexes of Schiff's bases with metals have gained significant attention due to antifungal, antibacterial, antiviral, antimalarial, and antitubercular activity. Metal complexes of Schiff bases containing halogens exhibit good antimicrobial activity [4]. Metal complexes of hydrazones are used as catalysts in different chemical reactions, such as the polymerization of alkenes [5].

In continuation of our previous work on the metal complexes [6-8]; in the present work, we report the synthesis of some new [1-(2-bromo, 5-methoxy benzylidene) hydrazine] ligand by the condensation of 2-bromo-5-methoxybenzaldehyde and hydrazine hydrate, which was characterized by using different spectroscopic techniques. Transition metal complexes were synthesized from the ligand and furthermore screened for antimicrobial, antitubercular, and antimalarial activities. 


\section{Materials and Methods}

All the purchased chemicals and solvents were analytical grade and used without further purification. Metal salts were used without further purification.

\subsection{Synthesis of [1-(2-Bromo-5-methoxybenzylidene)hydrazine] ligand.}

2-Bromo-5-methoxybenzaldehyde (1) (1 mmol) was mixed with hydrazine hydrate (2) (7 mmol) in ethanol (3 mL), and 1-2 drops of concentrated sulphuric acid were added to it. The mixture was refluxed for 4 hours at $80^{\circ} \mathrm{C}$. The progress of the reaction was monitored by Thin Layer Chromatography by using ethyl acetate:n-hexane $(2: 8)$ as the mobile phase. On completion of the reaction, the product was precipitated by cooling the reaction mixture and the addition of ice. The solid product was filtered off, dried, and recrystallized from ethanol, which was confirmed as the pure Schiff base ligand (3) by analysis of its spectroscopic data (Scheme 1).<smiles>COc1ccc(Br)c(C=O)c1</smiles>

(1)<smiles>NNCCCCC(=O)O</smiles>

(2)<smiles>COc1ccc(Br)c(C=NN)c1</smiles>

(3)

Scheme 1. Synthesis of [1-(2-Bromo, 5-methoxy benzylidene) Hydrazine] Ligand (1SA).

\subsection{Spectral data of synthesized ligand.}

Yield $=72 \%$, Yellow solid, M. P. $=162^{\circ}$ C; IR (FTIR-ATR, $\left.v \mathrm{~cm}^{-1}\right): 3045(\mathrm{NH}), 1620$ (Imine $\mathrm{C}=\mathrm{N}$ ).

\subsection{General procedure for the synthesis of metal complexes.}

The ethanolic solution of metal salts (nitrates or chlorides) was added to the ethanolic solution of the ligand. A slightly basic $\mathrm{p}^{\mathrm{H}}$ of the mixture was maintained by adding ammonia, and the contents were refluxed for 5-6 h. The progress of the reaction was monitored by TLC. The resulting product was cooled, filtered off, and dried. Each product was recrystallized from ethanol and confirmed by IR and UV spectroscopy (Scheme 2).
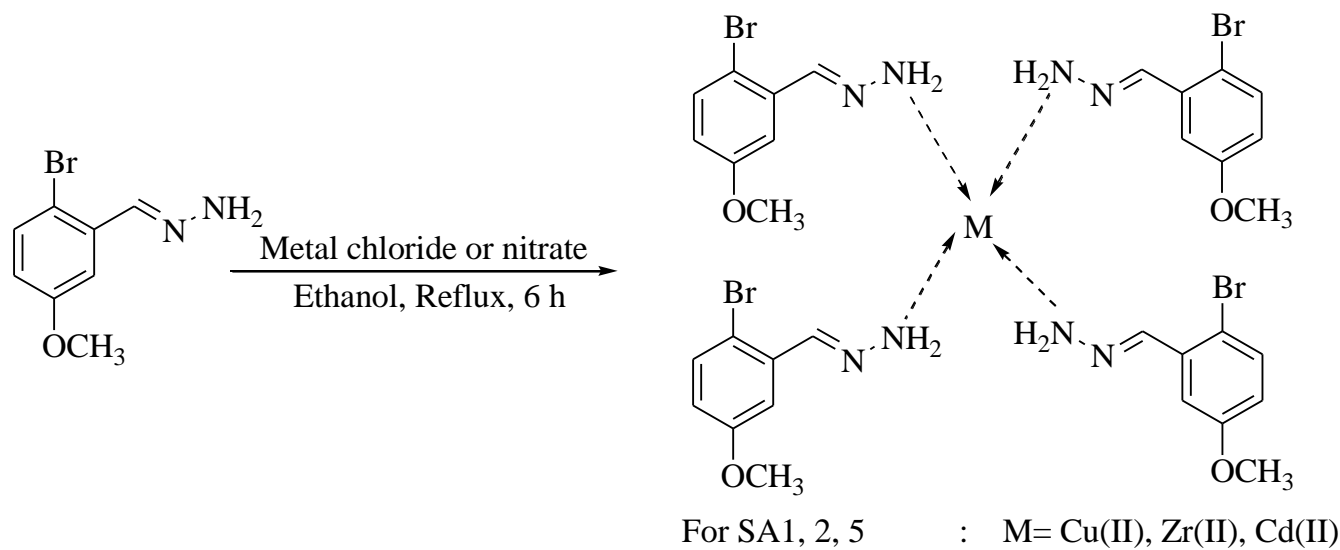

For $\mathrm{SA} 3,4,6,7,8: \mathrm{M}=\mathrm{Fe}(\mathrm{II}), \mathrm{Co}(\mathrm{II}), \mathrm{Sn}(\mathrm{II}), \mathrm{Ni}(\mathrm{II})$ and $\mathrm{Zn}(\mathrm{II})$

Scheme 2. Synthesis of metal complexes (SA1-8). 
The physical and analytical data of the synthesized compounds are mentioned in Table 1.

Table 1. Physical and analytical data of the synthesized compounds.

\begin{tabular}{|c|c|c|c|c|c|c|c|c|c|}
\hline \multirow[t]{2}{*}{$\begin{array}{l}\text { Sr. } \\
\text { No. }\end{array}$} & \multirow[t]{2}{*}{ Compound } & \multirow[t]{2}{*}{ Code } & \multirow[t]{2}{*}{ Molecular formula } & \multirow[t]{2}{*}{$\begin{array}{l}\text { M.P. } \\
\left({ }^{\circ} \mathbf{C}\right)\end{array}$} & \multirow[t]{2}{*}{ Color } & \multicolumn{4}{|c|}{$\begin{array}{c}\text { Elemental analysis (\%): } \\
\text { Calculated }\end{array}$} \\
\hline & & & & & & $\mathrm{C}$ & $\mathrm{H}$ & $\mathrm{N}$ & $\mathrm{M}$ \\
\hline 1 & Ligand (L) & 1SA & $\mathrm{C}_{8} \mathrm{H}_{9} \mathrm{~B}_{\mathrm{r}} \mathrm{N}_{2} \mathrm{O}$ & 162 & Yellow & 41.94 & 3.96 & 12.23 & - \\
\hline 2 & $\mathrm{CuL}_{4}$ & SA1 & $\mathrm{C}_{32} \mathrm{H}_{36} \mathrm{Br} 4 \mathrm{~N}_{8} \mathrm{O}_{4} \mathrm{Cu}$ & 247 & Light Green & 39.22 & 3.67 & 11.43 & 6.48 \\
\hline 3 & $\mathrm{ZrL}_{4}$ & SA2 & $\mathrm{C}_{32} \mathrm{H}_{36} \mathrm{Br}_{4} \mathrm{~N}_{8} \mathrm{O}_{4} \mathrm{Zr}$ & $>300$ & Yellowish White & 38.14 & 3.57 & 11.12 & 9.05 \\
\hline 4 & $\mathrm{FeL}_{4}$ & SA3 & $\mathrm{C}_{32} \mathrm{H}_{36} \mathrm{Br}_{4} \mathrm{~N}_{8} \mathrm{O}_{4} \mathrm{Fe}$ & 270 & Light Red & 39.53 & 3.70 & 11.52 & 5.74 \\
\hline 5 & $\mathrm{CoL}_{4}$ & SA4 & $\mathrm{C}_{32} \mathrm{H}_{36} \mathrm{Br}_{4} \mathrm{~N}_{8} \mathrm{O}_{4} \mathrm{Co}$ & 230 & Light Pink & 39.3 & 3.69 & 11.48 & 6.04 \\
\hline 6 & $\mathrm{CdL}_{4}$ & SA5 & $\mathrm{C}_{32} \mathrm{H}_{36} \mathrm{Br}_{4} \mathrm{~N}_{8} \mathrm{O}_{4} \mathrm{Cd}$ & $>300$ & Yellowish White & 37.36 & 3.49 & 10.89 & 10.92 \\
\hline 7 & $\mathrm{SnL}_{4}$ & SA6 & $\mathrm{C}_{32} \mathrm{H}_{36} \mathrm{Br}_{4} \mathrm{~N}_{8} \mathrm{O}_{4} \mathrm{Sn}$ & 240 & Ivory & 37.13 & 3.47 & 10.82 & 11.41 \\
\hline 8 & $\mathrm{NiL}_{4}$ & SA7 & $\mathrm{C}_{32} \mathrm{H}_{36} \mathrm{Br}_{4} \mathrm{~N}_{8} \mathrm{O}_{4} \mathrm{Ni}$ & 260 & Yellowish White & 39.41 & 3.69 & 11.49 & 6.01 \\
\hline 9 & $\mathrm{ZnL} 4$ & SA8 & $\mathrm{C}_{32} \mathrm{H}_{36} \mathrm{Br}_{4} \mathrm{~N}_{8} \mathrm{O}_{4} \mathrm{Zn}$ & 236 & Yellowish White & 39.15 & 3.66 & 11.41 & 6.71 \\
\hline
\end{tabular}

\subsection{Infrared spectra.}

The band due to the N-H stretch of free ligand was found to be shifted to the lower side in the spectra of all complexes, which indicate the participation of the $\mathrm{N}-\mathrm{H}$ group in the formation of complexes. Infrared spectral data $v \mathrm{~cm}^{-1}$ [9] for $\mathrm{C}=\mathrm{N}, \mathrm{M}-\mathrm{N}, \mathrm{C}-\mathrm{H}$ of metal complexes is presented in Table 2.

Table 2. Infrared spectral data of metal complexes.

\begin{tabular}{|c|c|c|c|c|c|}
\hline Code no & Compound & $v \mathrm{~cm}^{-1}(\mathrm{C}=\mathrm{N})$ & $v \mathrm{~cm}^{-1}(\mathrm{M}-\mathrm{N})$ & $v \mathrm{~cm}^{-1}(\mathrm{C}-\mathrm{H})$ & $v \mathrm{~cm}^{-1}(\mathrm{~N}-\mathrm{H})$ \\
\hline SA1 & $\mathrm{CuL}_{4}$ & 1608 & 439.77 & 3070 & 2962 \\
\hline SA2 & $\mathrm{ZrL} 4$ & 1614 & 455.20 & 3072 & 2954 \\
\hline SA3 & $\mathrm{FeL}_{4}$ & 1614 & 451.34 & 3080 & 2958 \\
\hline SA4 & $\mathrm{CoL}_{4}$ & 1610 & 453.27 & 3010 & 2958 \\
\hline SA5 & $\mathrm{CdL}_{4}$ & 1616 & 453.27 & 3080 & 2958 \\
\hline SA6 & $\mathrm{SnL}_{4}$ & 1618 & 457.13 & 3072 & 2958 \\
\hline SA7 & $\mathrm{NiL}_{4}$ & 1616 & 395.41 & 3080 & 2958 \\
\hline SA8 & $\mathrm{ZnL}_{4}$ & 1614 & 453.27 & 3010 & 2958 \\
\hline
\end{tabular}

2.5. UV spectra of the complex.

UV spectra of the synthesized metal complexes were recorded in DMSO solvent. $\lambda_{\max }$ value in the UV spectra of metal complexes is reported in Table 3.

Table 3. $\lambda_{\max }$ value of the synthesized metal complexes.

\begin{tabular}{c|c|c|c} 
Sr. No. & Compound & Sample code & Wavelength $\left(\boldsymbol{\lambda}_{\max }\right)$ \\
\hline 1 & $\mathrm{CuL}_{4}$ & $\mathrm{SA} 1$ & 222.8 \\
\hline 2 & $\mathrm{ZrL} 4$ & $\mathrm{SA} 2$ & 213.60 \\
\hline 3 & $\mathrm{FeL} 4$ & $\mathrm{SA} 3$ & 214.95 \\
\hline 4 & $\mathrm{CoL} 4$ & $\mathrm{SA} 4$ & 216.4 \\
\hline 5 & $\mathrm{CdL} 4$ & $\mathrm{SA} 5$ & 222.86 \\
\hline 6 & $\mathrm{SnL} 4$ & $\mathrm{SA6}$ & 217.53 \\
\hline 7 & $\mathrm{NiL} 4$ & $\mathrm{SA} 7$ & 212.20 \\
\hline 8 & $\mathrm{ZnL} 4$ & $\mathrm{SA} 8$ & 300.60
\end{tabular}

\subsection{Biological activity.}

2.6.1. Antimicrobial study.

The newly synthesized metal complexes were evaluated against four bacteria (E. coliMTCC 443, P. aeruginosa- MTCC 1688, S. aureus-MTCC 96, S. pyogenus- MTCC 442) and three fungal species (C. albicans- MTCC 227, A. niger- MTCC 282, and A. clavatus- MTCC 1323). 
The broth dilution method was used for antimicrobial activity [10]. The nutrient medium Mueller Hinton Broth was used to grow and dilute the drug/compound suspension for the microorganisms under test. Solutions of metal complexes were prepared in DMSO solvent. The solution of DMSO (without compound) was used as the control. Each synthesized compound was diluted to get a stock solution of 2000 microgram $/ \mathrm{mL}$ concentration. For primary screening, 1000 microgram $/ \mathrm{mL}, 500$ microgram $/ \mathrm{mL}$ and 250 microgram $/ \mathrm{mL}$ concentrations of the synthesized metal complexes were taken. The metal complexes found active in the primary screening were further subjected to all microorganisms for secondary screening. In secondary screening, the metal complexes (found active in primary screening) were diluted to get $200 \mathrm{microgram} / \mathrm{mL}, 100 \mathrm{microgram} / \mathrm{mL}, 50$ microgram $/ \mathrm{mL}, 25$ microgram $/ \mathrm{mL}, 12.5 \mathrm{microgram} / \mathrm{mL}$, and $6.25 \mathrm{microgram} / \mathrm{mL}$ concentrations. The control tube, which does not contain the test compound, was sub-cultured with a medium suitable for the growth of the test microbes and placed for incubation at $37^{\circ} \mathrm{C}$ overnight. The tubes are then incubated overnight. The Minimum Inhibitory Concentration (MIC) of the control test organism is recorded to examine the accuracy of concentrations of test compounds. Before incubation, the extent of growth from the control tube (which served as original inoculums) was compared. The MIC was recorded as the least concentration inhibiting the growth of the organism [11]. The MIC for newly synthesized metal complexes were compared with respective standard drugs for bacteria and fungi, as given in Table 4.

Table 4. Antimicrobial activity of the synthesized metal complexes.

\begin{tabular}{|c|c|c|c|c|c|c|c|c|}
\hline \multirow[t]{3}{*}{ Compound } & \multirow[t]{2}{*}{ Code } & \multicolumn{4}{|c|}{ Antibacterial Activity } & \multicolumn{3}{|c|}{$\begin{array}{c}\text { Antifungal Activity } \\
\text { Minimal Inhibition Concentration }\end{array}$} \\
\hline & & E. Coli & P. Aeruginosa & S. Aureus & S. Pyogenus & C. Albicans & A. Niger & A. Clavatus \\
\hline & & $\begin{array}{l}\text { MTCC } \\
443\end{array}$ & MTCC 1688 & MTCC 96 & MTCC 442 & MTCC 227 & $\begin{array}{l}\text { MTCC } \\
282\end{array}$ & MTCC 1323 \\
\hline $\mathrm{CuL}_{4}$ & SA1 & 25 & 50 & 125 & 100 & $>1000$ & 250 & 500 \\
\hline $\mathrm{ZrL}_{4}$ & SA2 & 50 & 100 & 25 & 62.5 & 1000 & 1000 & 1000 \\
\hline $\mathrm{FeL}_{4}$ & SA3 & 100 & 500 & 250 & 250 & 500 & 500 & $>1000$ \\
\hline $\mathrm{CoL}_{4}$ & SA4 & 50 & 250 & 100 & 500 & 500 & 1000 & 500 \\
\hline $\mathrm{CdL}_{4}$ & SA5 & 62.5 & 100 & 100 & 250 & 250 & 500 & 1000 \\
\hline $\mathrm{SnL}_{4}$ & SA6 & 100 & 62.5 & 100 & 62.5 & 500 & 1000 & 500 \\
\hline $\mathrm{NiL}_{4}$ & SA7 & 100 & 250 & 250 & 100 & 1000 & $>1000$ & $>1000$ \\
\hline $\mathrm{ZnL}_{4}$ & SA8 & 250 & 12.5 & 100 & 62.5 & 250 & 500 & 500 \\
\hline Ampicillin & Std* & 100 & - & 250 & 100 & - & - & - \\
\hline Chloramphenicol & Std* & 50 & 50 & 50 & 50 & - & - & - \\
\hline Gentamycin & Std* & 0.05 & 1 & 0.25 & 0.5 & - & - & - \\
\hline Ciprofloxacin & Std* & 25 & 25 & 50 & 50 & - & - & - \\
\hline Norfloxacin & Std* & 10 & 10 & 10 & 10 & - & - & - \\
\hline Nystatin & Std* & - & - & - & - & 100 & 100 & 100 \\
\hline Greseofulvin & Std* & - & - & - & - & 500 & 100 & 100 \\
\hline
\end{tabular}

2.6.2. Anti-tubercular activity.

All the synthesized metal complexes were used for an antitubercular activity. Mycobacterium Tuberculosis strain (H37Rv) cultures were tested against the synthesized metal complexes. We used MIC to assess the anti-tuberculosis activity. This simple method gives a significant result for the number of antimicrobial agents that are required for inhibiting the growth of specific microbes [12].

The nutrient medium was used to grow microorganisms by the conventional L. J. medium. The size of the inoculum was fixed to $1 \mathrm{mg} / \mathrm{mL}$ for test strain. DMSO was used as a solvent to obtain desired concentrations of test compounds. Each synthesized metal complex 
was diluted to yield $2000 \mu \mathrm{g} / \mathrm{mL}$ concentration as a stock solution. Serial dilutions were prepared for primary and secondary screening; $500 \mu \mathrm{g} / \mathrm{mL}, 250 \mu \mathrm{g} / \mathrm{mL}$, and $125 \mu \mathrm{g} / \mathrm{mL}$ concentrations of the synthesized metal complexes were taken in primary screening. The synthesized complexes which were found active in primary screening were promoted for secondary screening against $M$. Tuberculosis strain. In secondary screening, the synthesized metal complexes (found active in primary screening) were diluted to yield $100 \mu \mathrm{g} / \mathrm{mL}, 50 \mu \mathrm{g}$ $/ \mathrm{mL}, 25 \mu \mathrm{g} / \mathrm{mL}, 12.5 \mu \mathrm{g} / \mathrm{mL}, 6.250 \mu \mathrm{g} / \mathrm{mL}, 3.125 \mu \mathrm{g} / \mathrm{mL}$ and $1.5625 \mu \mathrm{g} / \mathrm{mL}$ concentrations. MIC is recorded as the maximum dilution showing at least $99 \%$ inhibition. MIC of the synthesized metal complexes was determined and compared with standard Isoniazid and Rifampicin drugs, as given in Table 5, which provides data for antitubercular activity.

Table 5. Antitubercular activity against $\mathrm{H}_{37} \mathrm{RV}$ stain.

\begin{tabular}{l|l|l} 
Code & Compound & $\mathbf{M I C}(\boldsymbol{\mu g} / \mathbf{m L})$ \\
\hline SA1 & CuL4 & 250 \\
\hline SA2 & ZrL4 & 500 \\
\hline SA3 & FeL4 & 125 \\
\hline SA4 & CoL4 $_{4}$ & 100 \\
\hline SA5 & CdL4 $_{4}$ & 250 \\
\hline SA6 & SnL$_{4}$ & 100 \\
\hline SA7 & $\mathrm{NiL}_{4}$ & 62.5 \\
\hline SA8 & ZnL4 & 125 \\
\hline Standard & Isoniazid & $0.20 \mu \mathrm{g} / \mathrm{mL}(99 \%$ inhibition $)$ \\
\hline Standard & Rifampicin & $40 \mu \mathrm{g} / \mathrm{mL}(99 \%$ inhibition $)$
\end{tabular}

\subsubsection{Antimalarial activity.}

The synthesized metal complexes were screened for antimalarial activity by using the microassay protocol of Rieckmann K.H. and co-workers with slight modifications. The simple in-vitro assay used for the determination of susceptibility of Plasmodium falciparum to antimalarial compounds was performed in 96 well microtitre plates. RPMI 1640 medium was used to maintain the cultures of $P$. Falciparum strain. The culture medium was supplemented with $1 \%$ D-glucose, $25 \mathrm{mM}$ HEPES, $10 \%$ heat-inactivated human serum, and $0.23 \%$ sodium bicarbonate.

On treatment with 5\% D-sorbitol, the asynchronous parasites of Plasmodium falciparum were synchronized to get only the ring stage parasitized cells. Each of the test compounds was diluted by using DMSO to obtain $5 \mathrm{mg} / \mathrm{mL}$ concentration as a stock solution, and subsequent dilutions were prepared with a culture medium. $20 \mu \mathrm{L}$ of the diluted samples were added to the test wells so as to get final concentrations varying between $0.4 \mu \mathrm{g} / \mathrm{mL}$ to 100 $\mu \mathrm{g} / \mathrm{mL}$ in duplicate wells containing parasitized cell preparation. In a candle jar, the culture plates were incubated for 36 to $40 \mathrm{~h}$ at $37^{\circ} \mathrm{C}$. After incubation, lean blood smears from each well were prepared and stained with J. S. Bhattacharya staining. The slides were examined microscopically, and the maturation of ring-stage parasites into trophozoites and schizonts was recorded in the presence of different concentrations of test compounds. The least concentration of test compound, which inhibits the complete maturation into schizonts, was reported as the MIC value. Quinine and Chloroquine were used as standard drugs. The antimalarial activity of the synthesized metal complexes is summarized in Table 6. 
Table 6. Minimal inhibition concentrations for antimalarial activity.

\begin{tabular}{l|ll} 
Code no. & Compound & Mean IC50 values \\
\hline SA1 & CuL4 & $1.68 \mu \mathrm{g} / \mathrm{ml}$ \\
\hline SA2 & ZrL4 & $1.42 \mu \mathrm{g} / \mathrm{ml}$ \\
\hline SA3 & FeL4 & $0.63 \mu \mathrm{g} / \mathrm{ml}$ \\
\hline SA4 & CoL4 & $2.06 \mu \mathrm{g} / \mathrm{ml}$ \\
\hline SA5 & CdL4 & $0.48 \mu \mathrm{g} / \mathrm{ml}$ \\
\hline SA6 & $\mathrm{SnL}_{4}$ & $1.17 \mu \mathrm{g} / \mathrm{ml}$ \\
\hline SA7 & NiL4 & $1.03 \mu \mathrm{g} / \mathrm{ml}$ \\
\hline SA8 & ZnL4 & $1.07 \mu \mathrm{g} / \mathrm{ml}$ \\
\hline \multirow{2}{\text{Standard}}{} & Chloroquine & IC $50-0.020 \mu \mathrm{g} / \mathrm{ml}$ \\
\cline { 2 - 3 } & Quinine & IC $50-0.268 \mu \mathrm{g} / \mathrm{ml}$
\end{tabular}

\section{Results and Discussion}

A new ligand [1-(2-Bromo-5-methoxybenzylidene) hydrazine] was synthesized from 2-bromo-5-methoxybenzaldehyde and hydrazine hydrate, which was further used as a ligand for the synthesis of metal complexes. Newly synthesized ligand and metal complexes were characterized by different spectroscopic methods. Metal complexes were evaluated for antimicrobial, antitubercular, and antimalarial activities. The IR spectrum of ligand shows broadband in the region $1620 \mathrm{~cm}^{-1}$, corresponding to the stretching frequency for the $\mathrm{C}=\mathrm{N}$ group. For metal complexes, the spectral band in the region of $395 \mathrm{~cm}^{-1}$ to $457 \mathrm{~cm}^{-1}$ indicates $\mathrm{M}-\mathrm{N}$ band frequency i. e. nitrogen of ligand and metal was co-ordinated. The IR band at 3000 $\mathrm{cm}^{-1}$ to $3150 \mathrm{~cm}^{-1}$ corresponds to the stretching frequency of $\mathrm{C}-\mathrm{H}$ bonds. The ligand behaves as monodentate, co-ordinating to the metal ion through the nitrogen atom of $\mathrm{NH}_{2}$ group of the ligand.

In the UV spectra, $\lambda_{\max }$ value for metal complexes ranges from $213 \mathrm{~nm}$ to $300 \mathrm{~nm}$. $\mathrm{Zn}(\mathrm{II})$, i.e., $\left(\mathrm{ZnL}_{4}\right)$ showed $\lambda_{\max }$ value at higher absorption. The metal complexes of $\mathrm{Cu}(\mathrm{II})$, $\mathrm{Zr}$ (II), $\mathrm{Fe}(\mathrm{II}), \mathrm{Co}(\mathrm{II}), \mathrm{Cd}(\mathrm{II}), \mathrm{Sn}(\mathrm{II}), \mathrm{Ni}(\mathrm{II})$, and $\mathrm{Zn}$ (II) were formed in ligand to metal ratio of 4:1.

The results of the antimicrobial activity of the metal complexes showed that $\mathrm{Cu}(\mathrm{II})$ and $\mathrm{Zn}$ (II) exhibited excellent activity against $P$. Aeruginosa (MTCC 1688), S. Aureus (MTCC 96), and S. Pyogenus (MTCC 442). Ni(II) and Sn(II) showed activity against S. Pyogenus (MTCC 442). $\mathrm{Cu}$ (II) and $\mathrm{Zr}$ (II) showed remarkable activity against E. coli (MTCC 443) as compared with the standard drugs. $\mathrm{Cd}(\mathrm{II})$ and $\mathrm{Zn}$ (II) showed moderate to excellent activity against $C$. albicans (MTCC 227), A. Niger (MTCC 282), and A. Clavatus (MTCC 1323). Cu(II) showed good activity against $A$. niger (MTCC 282), Co(II) and Sn(II) were remarkably active against A. Clavatus (MTCC 1323) as compared with the standard drugs. The antitubercular activity of the synthesized metal compounds revealed moderate to excellent activity for $\mathrm{Ni}$ (II) complex against MTB strain (H37Rv) while $\mathrm{Co}(\mathrm{II})$ and $\mathrm{Sn}$ (II) were active against MTB as compared to the standard drugs isoniazid and rifampicin. Antimalarial activity of the synthesized compounds was good for the $\mathrm{Cd}(\mathrm{II})$, while $\mathrm{Fe}(\mathrm{II})$ was active against malaria as compared to the standard drugs chloroquine and quinine.

\section{Conclusions}

In conclusion, monodentate Schiff base [1-(2-Bromo-5-methoxy benzylidene) hydrazine] ligand and its metal complexes were synthesized and characterized by different spectroscopic methods. Antimicrobial activity, antitubercular and antimalarial activity of the synthesized metal complexes indicate that $\mathrm{Cu}(\mathrm{II})$ and $\mathrm{Zn}$ (II) showed excellent antimicrobial 
activity, $\mathrm{Ni}(\mathrm{II})$ was remarkably active against MTB while $\mathrm{Cd}(\mathrm{II})$ showed excellent activity against the malarial strain as compared to the respective standard drugs.

\section{Funding}

This research received no external funding.

\section{Acknowledgments}

The authors are thankful to the Principal, Deogiri College, Aurangabad (MS) India, for providing necessary laboratory facilities.

\section{Conflicts of Interest}

The authors declare no conflict of interest.

\section{References}

1. More, M.S.; Joshi, P.G.; Mishra, Y.K.; Khanna, P.K. Metal complexes driven from Schiff bases and semicarbazones for biomedical and allied applications: a review. Materials Today Chemistry 2019, 14, https://doi.org/10.1016/j.mtchem.2019.100195

2. Omidi, S.; Kakanejadifard, A. A review on biological activities of Schiff base, hydrazone, and oxime derivatives of curcumin. RSC Advances 2020, 10, 30186-30202, https://doi.org/10.1039/D0RA05720G.

3. Pitchumani, M.C.; Shankar, R.; Vijayakumar, S. Theoretical insights into the metal chelating and antimicrobial properties of the chalcone based Schiff bases. Molecular Simulation 2019, 45, 636-645, https://doi.org/10.1080/08927022.2019.1573370.

4. Arulmurugan, S.; Kavitha, H.; Venkatraman, B.R. Biological activities of Schiff base and its complexes. Rasayan Chemistry 2010, 3, 385-410

5. Wolf, R.A.; Warakomski, J.M. Multi-sited hydrazone initiators of vinyl polymerization. United States patent US 4, 855, 373, 1989.

6. Bhale, S.; Gore, V.; Tekale, S.; Pawar, R. Synthesis, characterization and antimicrobial activity of Ni(II), $\mathrm{Zn}(\mathrm{II})$, and $\mathrm{Cd}(\mathrm{II})$ complexes of 3/4-bromo-benzoic acid (phenyl-pyridine-2-yl-methylene)-hydrazide ligand. Letters in Applied NanoBioScience 2020, 9, 1529-1537.

7. Ambhure, R.U.; Mirgane, S.R.; Thombal, D.U.; Nawale, R.B.; Marathe, R.P.; Pawar, R.P. Synthesis and antibacterial study of some Schiff bases complexes. Journal of Modern Organic Chemistry Research 2017, 2, 11-16, https://dx.doi.org/10.22606/mocr.2017.21003

8. Pawar, S.S.; Patil, C.S.; Tadke, V.B.; Pawar, R.P. Synthesis, Characterization and biological activity of NiMn tartarate-mixed metal complexes. I.J. Current Advanced Research 2018, 7, 12934-37

9. Chitrapriya, N.; Kamatchi, T.S.; Zeller, M.; Lee, H.; Natrajan, K. Synthesis, spectroscopic, crystal structure and DNA binding of Ru(II) complexes with 2-hydroxy-benzoic acid [1-(4-hydroxy-6-methyl-2-oxo-2Hpyran-3-yl)-ethylidene]-hydrazide. $\quad$ Spectrochimica $\quad$ Acta $\quad \mathbf{2 0 1 1}, \quad 81, \quad$ 128-134, https://doi.org/10.1016/j.saa.2011.05.069.

10. Donovick, R.; Hamre, D.; Kavanagh, F.; Rake, G. A broth dilution method of assaying streptothricin and streptomycin. Journal of Bacteriology 1945, 50, 623-628,

11. Wiegand, I.; Hilpert, K.; Hancock, R.E. Agar and broth dilution methods to determine the minimal inhibitory concentration (MIC) of antimicrobial substances. Nature Protocols 2008, 3, 163-175, https://doi.org/10.1038/nprot.2007.521.

12. Banfi, E.; Scialino, G.; Monti-Bragadin, C. Development of a microdilution method to evaluate Mycobacterium tuberculosis drug susceptibility. Journal of Antimicrobial Chemotherapy 2003, 52, 796-800, https://doi.org/10.1093/jac/dkg439. 